\title{
The influence of the inquiry learning model and learning style on the drawing technique of students
}

\author{
Muhammad Rais, Farida Aryani \& Ansari S. Ahmar
}

Universitas Negeri Makassar

Makassar, Indonesia

\begin{abstract}
The purpose of this study was the following: to examine the influence of the inquiry learning model on students drawing technique ability; to examine the influence of learning style on students' drawing technique and to examine the joint influence of the inquiry learning model and learning style on students' drawing technique. A quasi-experimental approach was applied to this study, with a non-equivalent control group and $2 \times 3$ factorial design. There were 79 students as participants from the Engineering Faculty of the Universitas Negeri Makassar (State University of Makassar), Indonesia. Research data were analysed using an analysis of variance. The results show that there was an influence on students' drawing technique from the inquiry learning model and learning style.
\end{abstract}

Keywords: Inquiry learning, learning style, drawing technique

\section{INTRODUCTION}

One of the important aspects of the learning process is to examine the learning experience to determine how students learn. DePorter says that learning is dynamic and full of risks [1]. Witkin and Goodenough consider that the learning process consists of three steps, viz. acquisition, storage and retrieval [2]. There are various methods implemented as part of the learning process to facilitate students in remembering, understanding, implementing and evaluating. Every method has advantages and disadvantages compared with other methods. In the learning process, an educator should choose an appropriate method relevant to the needs of the students.

The inquiry method is one of the strategies used by teachers to inculcate independent learning in the students. By using this method, students will try to find a solution to every problem faced in the learning process. Intrinsically, the inquiry method is appropriate where students are expected to grasp the procedures, facts and concepts of a scientific discipline. The inquiry method can be used to teach students a specific concept, fact or skill needed to tackle a problem [3].

By implementing the inquiry method, the critical thinking skills of students can be improved, such as how to develop a question; how to source information; and how to identify a new aspect of a problem [4-6].

Another factor, which can influence students' success in the learning process is the learning style of students. Students have various learning styles and so this is an important area that needs to be examined [7-11].

In this study, an examination was made of the influence of learning method and learning style in improving a student's drawing technique. Both aspects, learning method and learning style, can be said to be independent variables, which can influence the student's ability in drawing technique; therefore, it is the dependent variable, drawing technique that is the object of study in this research.

\section{METHOD}

A quasi-experimental approach was applied to this study, to find the relationship among the research variables [12-14]. Two groups were organised for study, i.e. an experiment group and a control group. The experiment group used the inquiry method, while the control group used an expository method. For the research, a factorial 2 x 3 design was 
applied to the non-equivalent control groups [15]. The aim of this design was to examine separately the influence of the two independent variables on the dependent variable [16][17].

The learning method was an independent variable, which could take the values inquiry method or expository method. The other independent variable was learning style, which could take the values visual, auditory or kinesthetic. Learning style was measured using the visual auditory kinesthetic (VAK) scale developed by DePorter [1][18-20]. The dependent variable of the study was the student's ability in drawing technique.

Participants of this study were students of the Department of Agriculture at the Universitas Negeri Makassar (State University of Makassar), Indonesia, in their second semester. There were 79 student participants divided into two classes with 40 students in class A, the experiment class, and 39 students in class B, the control class. The VAK scale used for this study measures the learning style of students through a check-list instrument. This measures ten aspects of students' drawing technique, viz.

1. conceiving the technical picture as a language;

2. making a measurement line;

3. making a measurement number;

4. making a picture line;

5. designing picture etiquette;

6. making a projection line;

7. reading an American projection;

8. reading a European projection;

9. drawing an American projection;

10. drawing a European projection.

Data collection techniques used were scales/instruments, interviews and observation. The data were tested by applying the Kolmogorov-Smirnov test (K-S test or KS test) to determine the normality level of the data and the data were analysed using analysis of variance (ANOVA) [13]. The ANOVA was carried out with a 2 x 3 factorial design to test the research hypothesis, and a double ANOVA was applied to test the different effects of the two independent variables. The significant level was 0.05 (5\%), and the data analysis software used was SPSS 21.00 for Windows.

\section{RESULTS}

\section{Description of Learning Style Variable}

Table 1 shows the distribution of participants by the independent variables, learning style and learning method, displayed as a 3 x 2 matrix of values together with totals.

Table 1: Distribution of participants by learning style and learning method.

\begin{tabular}{|l|c|c|c|}
\cline { 2 - 4 } \multicolumn{1}{c|}{} & Inquiry method & Expository method & Total \\
\hline Visual & 7 & 12 & 19 \\
\hline Auditory & 16 & 9 & 25 \\
\hline Kinaesthetic & 17 & 18 & 35 \\
\hline Total & 40 & 39 & 79 \\
\hline
\end{tabular}

Pre-test and post-test data for the dependent variable student drawing technique ability is shown in Table 2.

Table 2: Pre-test and post-test data for student drawing technique ability.

\begin{tabular}{|c|c|c|c|c|}
\hline No. & Learning method & Learning style & Pre-test mean (M) & Post-test mean (M) \\
\hline 7 & \multirow{4}{*}{ Inquiry } & Visual & 26.57 & 35.43 \\
\hline 16 & & Auditory & 25.75 & 37.19 \\
\hline 17 & & Kinaesthetic & 28.06 & 38.18 \\
\hline 40 & & Inquiry mean & 26.86 & 37.30 \\
\hline 12 & \multirow{4}{*}{ Expository } & Visual & 26.08 & 32.58 \\
\hline 9 & & Auditory & 25.33 & 34.22 \\
\hline 18 & & Kinaesthetic & 25.22 & 34.94 \\
\hline 39 & & Expository mean & 25.51 & 34.05 \\
\hline
\end{tabular}

Based on Table 2, it can be seen that the control group pre-test ability was 25.51, which increased to 34.05 post-test, whereas the experiment group ability increased from 26.86 pre-test to 37.30 post-test. 
The results from testing the hypotheses related to the effect of the enquiry learning and expository learning methods on student drawing technique are shown in Table 3. There are three conclusions that can be drawn from Table 3:

1. There is a significant difference related to student ability between the experiment group, which used the inquiry learning method, and the control group, which used the expository method, with the former being superior. This is based on the learning method's $\mathrm{F}$ value $=16.489$ being greater than $\mathrm{F}$ table $=3.96$.

2. There is a significant difference related to the students' ability, between students who learn using visual, auditory and kinesthetic style. This is based on the learning style $\mathrm{F}$ value $=3.973$ being greater than $\mathrm{F}$ table $=3.96$.

3. The learning method (inquiry and expository) and learning style (visual, auditory and kinesthetic) do not together influence a student's ability. This is based on the learning method *learning style $\mathrm{F}$ value $=0.027$ being less than $\mathrm{F}$ table $=3.92$.

Table 3: The ANOVA test of learning method and learning style for drawing technique.

\begin{tabular}{|l|c|c|c|c|c|}
\hline \multicolumn{1}{|c|}{ Source } & Type III sum of squares & df & Mean square & F & Sig. \\
\hline Corrected model & $286.670^{\mathrm{a}}$ & 5 & 57.334 & 5.945 & $<0.001$ \\
\hline Intercept & 87856.924 & 1 & 87856.924 & 9109.659 & $<0.001$ \\
\hline Learning methods & 159.025 & 1 & 159.025 & 16.489 & $<0.001$ \\
\hline Learning style & 76.642 & 2 & 38.321 & 3.973 & 0.023 \\
\hline Learning method *learning style & 0.514 & 2 & 0.257 & 0.027 & 0.974 \\
\hline Error & 704.039 & 73 & 9.644 & & \\
\hline Total & 101654.000 & 79 & & & \\
\hline Corrected total & 990.709 & 78 & & & \\
\hline
\end{tabular}

\section{DISCUSSION}

The results of this study showed that the inquiry learning method can significantly increase a student's drawing technique ability. This ability was based on the ten aspects mentioned above, i.e. conceiving the technical picture as a language; making a measurement line; making a measurement number; making a picture line; designing picture etiquette; making a projection line; reading an American projection; reading a European projection; drawing an American projection and drawing a European projection.

The value of an independent learning process can be seen in the approach students take to undertaking assignments [6][21][22]. The inquiry learning method encourages students to learn lesson material together.

Students have a variety of learning styles. It is shown from this study that this variable is not significant in predicting a student's ability in drawing technique. However, as outlined in the results above, there are other variables that are significant predictors of a student's ability.

Talent and motivation can be seen as dominant factors, which influence a student's interest in drawing technique. The learning syle has a role in guiding students toward finding information related to drawing techniques. Visual and kinesthetic learning styles help students to read graphs, tables, diagrams and pictures [23-25].

It is shown from this study that the inquiry method paired with the learning style does not positively influence the ability of students. It is determined from the statistical analysis that the inquiry method has a bigger impact on ability than learning style.

\section{CONCLUSIONS}

Based on the research, it was found that the inquiry learning method had a significant, positive influence on the students' ability in drawing technique. In addition, the learning style - visual, auditory or kinesthetic - also influenced the students' ability. Another finding is that both variables, learning style and inquiry method, did not jointly influence the ability of students. Further study should be undertaken related to other variables that could influence a student's ability.

\section{REFERENCES}

1. DePorter, B. and Hernacki, M., Quantum Learning. New York, USA: Dell Paperbacks (2002).

2. Witkin, H.A. and Goodenough, D.R., Cognitive styles: essence and origins. Field dependence and field independence. Psychol. Issues, 51, 1-141 (1981). 
3. Abdi, A., The effect of inquiry-based learning method on students' academic achievement in science course. Univers. J. of Educ. Research, 2, 1, 37-41 (2014).

4. Tseng, C.-H., Tuan, H.-L. and Chin, C.-C. How to help teachers develop inquiry teaching: perspectives from experienced science teachers. Research in. Science Educ., 43, 2, 809-825 (2013).

5. Duran, M. and Dökme, İ., The effect of the inquiry-based learning approach on student's critical-thinking skills. Eurasia J. of Math. Science and Technol. Educ., 12, 12 (2016).

6. Smallhorn, M., Young, J., Hunter, N. and da Silva, K.B., Inquiry-based learning to improve student engagement in a large first year topic. Student Success, 6, 2 (2015).

7. Winkel, W.S., Psikologi pendidikan dan evaluasi belajar. Gramedia (1983) (in Indonesian).

8. Kolb, D.A., Experiential Learning: Experience as the Source of Learning and Development. FT Press (2014).

9. Zhang, L.F. and Sternberg, R.J., Perspectives on Thinking, Learning, and Cognitive Styles. London: Lawrence Erlbaum Associates (2001).

10. Santrock, J.W., Psikologi Pendidikan, Edisi kedua (Alih Bahasa: Tri Wibowo BS), Jakarta Kencana Prenada Media Gr. (2011) (in Indonesian).

11. Lee, S.W., Encyclopedia of School Psychology. Sage (2005).

12. Vockell, E.L. and Asher, J.W. Educational Research. (2nd Edn), Englewood Cliffs, NJ: Macmillan (1995).

13. Gall, M.D., Gall, J.P. and Borg, W.R., Applying Educational Research: How to Read, Do, and Use Research to Solve Problems of Practice. Pearson Higher Ed (2014).

14. Salkind, N.J., Exploring Research. (6st Edn), New Jersey: Prentice Hal (2006).

15. Tuckman, B.W. and Harper, B.E., Conducting Educational Research. USA: Rowman \& Littlefield Publishers (2012).

16. Kerlinger, F.N., Aspek-aspek Penelitian Behavioral. Yogyakarta: Gajah Mada University Press (1990) (in Indonesian).

17. Sevilla, C.G., Ochave, J.A., Punsalan, T.G., Regala, B.P. and Uriarte, G.G., Pengantar metode penelitian. Jakarta: Penerbit Universitas Indonesia Press (1993) (in Indonesian).

18. Rahman, A. and Ahmar, A.S., Relationship between learning styles and learning achievement in mathematics based on genders. World Trans. on Engng. and Technol. Educ., 15, 1, 74-77 (2017).

19. Rahman, A., Ahmar, A.S. and Rusli, The influence of cooperative learning models on learning outcomes based on students’ learning styles. World Trans. on Engng. and Technol. Educ., 14, 3, 425-430 (2016).

20. Mulbar, U., Rahman, A. and Ahmar, A.S., Analysis of the ability in mathematical problem-solving based on SOLO taxonomy and cognitive style. World Trans. on Engng. and Technol. Educ., 15, 1, 68-73 (2017).

21. Myers, M.J. and Burgess, A.B., Inquiry-based laboratory course improves students' abilityt to design experiments and interpret data. Adv. Physiol. Educ., 27, 1, 26-33 (2003).

22. Weaver, G.C., Russell, C.B. and Wink, D.J., Inquiry-based and research-based laboratory pedagogies in undergraduate science. Nat. Chem. Biol., 4, 10, 577-580 (2008).

23. Whitman, N.A. and Schwenk, T.L., Preceptors as Teachers: a Guide to Clinical Teaching. UT: University of Utah School of Medicine (1984).

24. Miller, P., Learning Styles: the Multimedia of the Mind. Research Report. ED451140. Programs ED (2001).

25. Gokalp, M., The effect of students' learning styles to their academic success. Educ. Research. Review, 8, 17, 1634 (2013).

\section{BIOGRAPHIES}

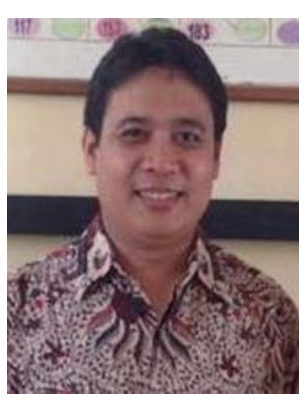

Muhammad Rais completed his doctoral degree in learning technology at Universitas Negeri Malang, Indonesia, in 2011. Earlier, he received his Master of Mechanical Engineering degree from the Universitas Brawijaya, Malang, Indonesia. Currently, he teaches mechanical engineering in the Faculty of Engineering at Universitas Negeri Makassar. He has taught many courses in the area of engineering, education and educational technology. He is actively involved in a number of research and training programmes, such as teachers' training and education; developing project-based learning; developing the guidelines for disaster mitigation education; and the reflective learning model.

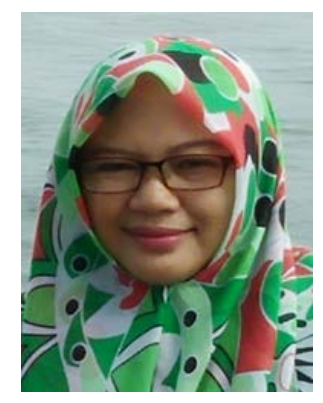

Farida Aryani received her doctoral degree in educational psychology and counselling from Universitas Negeri Malang in 2009. Since 2004, she has taught various courses in the area of psychology, education, counselling and career development. She is currently Chair of the Educational Psychology Programme at the Graduate School of Universitas Negeri Makassar. She is one of the more productive researchers and trainers in her field. Since 2010, she has been involved in a number of research and training programmes sponsored by USAID (United States Agency for International Development), ILO (International Labour Organisation) and UNICEF (United Nations Childrens' Fund). Her recent works include, among others, developing a peer counsellor programme; child abuse in Makassar, a baseline study; and developing career interest software. 
Ansari Saleh Ahmar is a lecturer in the Department of Statistics of the Faculty of Mathematics and Natural Sciences at Universitas Negeri Makassar, Indonesia. He graduated with a Bachelor's degree in mathematics at Universitas Negeri Makassar, Indonesia, in 2009. He received his Master's degree (MSc) in mathematics, specialising in statistics at Universitas Gadjah Mada, Indonesia, in 2013. Apart from being a lecturer, he is also a member of the Information Technology Team in the ICT Centre, Universitas Negeri Makassar. Ansari has also reviewed several articles on mathematics, statistics and IT. 